\title{
IDH2 Gene Mutation
}

National Cancer Institute

\section{Source}

National Cancer Institute. IDH2 Gene Mutation. NCI Thesaurus. Code C118390.

A change in the nucleotide sequence of the IDH2 gene. 